\title{
The role of vegetated areas on fish assemblage of the Paraná River floodplain: effects of different hydrological conditions
}

\author{
Juan José Neiff ${ }^{1}$, Alicia Poi de Neiff ${ }^{1,2}$ and Marta B. Canón Verón ${ }^{1}$
}

In this paper, we analyze the changes in composition and abundance of fish assemblages in seven vegetated floodplain wetlands with different connectivity across different hydrologic conditions: after a prolonged connection of the floodplain with the main channel, during receding water, and after a prolonged isolation. We also investigated the size and abundance of large-sized migratory species found in these wetlands and the food resources exploited by the dominant fish. Fishes were captured by diurnal seining ( $8.0 \mathrm{~m} \times 1.50 \mathrm{~m}, 5 \mathrm{~mm}$ mesh) along macrophyte banks. Despite the high total number of species registered (100), sample species richness varied between 7 and 31, depending on the sampling site and the sampling date. Cluster analysis indicated low similarity between sites during both the isolation and the prolonged connection. Species turnover decreased from high water ( $\beta$ $=40.33)$ to low water $(\beta=33.83)$, with the minimum value of beta diversity index obtained during the isolation of the floodplain wetlands $(\beta=26.83)$. Our results indicated that different dominant populations of fish occur in different hydrological conditions, even though high water and isolation phases occur in the same season of different years. The ordination (NMDS) indicated the importance of hydrologic conditions in structuring fish assemblages in the studied floodplain. Small-sized characids, typically associated with macrophytes, dominated the fish assemblages, whereas the younger stages of large sized migratory species were found in low abundance. The maximum standard length of the fish captured was $28 \mathrm{~cm}$ and for large migratory fish, standard length varied between 1.6 and $25.0 \mathrm{~cm}$. The dominant fish used several food resources, but littoral macrophytes-associated organisms had a high frequency of occurrence in the three hydrologic conditions. The high species richness of fish in the small, vegetated lakes was related to the high spatial heterogeneity during different hydrological conditions. Disturbances in the hydrological pulses could reduce the biodiversity by modifying the connectivity of the floodplain with the river channel. Conservation of these vegetated wetlands requires maintenance of actual width range of connectivity that provide diverse habitat along the time.

Neste artigo analisamos as mudanças na composição e abundância das assembléias de peixes de sete áreas úmidas de planície de inundação com vegetação e com diferentes conectividades e em diferentes condições hidrológicas: depois de uma conexão prolongada da planície de inundação com o canal principal, durante o recuo das águas e após um isolamento prolongado. Nós também investigamos o tamanho e abundância das espécies migratórias de grande tamanho encontradas nestas áreas úmidas e os recursos alimentares explorados pelas espécies dominantes. Os peixes foram capturados com rede durante o dia $(8.0 \mathrm{~m} \mathrm{x}$ $1.50 \mathrm{~m}$, malha de $5 \mathrm{~mm}$ ) nos bancos de macrófitas. Apesar do alto número de espécies registradas (100), a riqueza de espécies nas amostras variou entre 7 e 31, de acordo com o local e data de coleta. A análise de cluster indicou uma baixa similaridade entre os locais tanto durante o período de isolamento como no de conexão prolongada. A substituição de espécies decresceu do período de cheia $(\beta=40.33)$ a vazante $(\beta=33.83)$, com o valor mínimo de índice de diversidade beta obtido durante o isolamento das áreas úmidas da planície de inundação $(\beta=26.83)$. Os resultados indicaram que diferentes populações dominantes de peixes ocorrem em condições hidrológicas diferentes, mesmo quando fases de cheia e de isolamento ocorreram na mesma estação em anos diferentes. A ordenação (NMDS) indicou a importância das condições hidrológicas na estruturação das assembléias de peixes na planície de inundação estudada. Caracídeos de pequeno tamanho, tipicamente associados à macrófitas, dominaram a assembléia de peixes, enquanto que indivíduos jovens de espécies de maior porte e migratórias foram encontradas em baixa abundância. O comprimento padrão máximo dos peixes capturados foi de $28 \mathrm{~cm}$; para espécies migratórias de maior porte o comprimento padrão variou de 1,6 a $25 \mathrm{~cm}$. Os peixes dominantes utilizaram vários recursos alimentares, mas organismos associados às macrófitas litorâneas apresentaram uma alta frequência de ocorrência nas três condições hidrológicas. A alta riqueza de espécies de peixes nos pequenos lagos com vegetação foi relacionado à alta heterogeneidade espacial durante as diferentes condições hidrológicas. Distúrbios nos pulsos hidrológicos podem reduzir a biodiversidade pela modificação da conectividade da área de inundação com o canal principal do rio. A conservação das áreas úmidas com vegetação requer a manutenção da variação de conectividade a fim de proporcionar a diversidade de habitats ao longo do tempo.

Key words: Fish diversity, Fish diet, Floodplain wetlands, Aquatic plants.

${ }^{1}$ Consejo Nacional de Investigaciones Científicas y Técnicas, Centro de Ecología Aplicada del Litoral, C.C. 291, Corrientes, Argentina. jj@neiff.com.ar

${ }^{2}$ Universidad Nacional del Nordeste, Departamento de Biología, Corrientes, Argentina. 


\section{Introduction}

Hydrological regime is considered the key factor driving biodiversity pattern in riverine tropical and subtropical wetlands (Junk et al., 1989; Neiff, 1990). Floodplains of large rivers encompass an array of ecosystem types and flooding regimes, which are characterized by high levels of habitat diversity and biotic spatial gradients in relation to the connectivity of different patches across the riverine landscape (Welcomme, 1985; Ward et al., 1999; Neiff, 2001). Comparisons between the main channel and the floodplain indicated that the number of individuals caught per unit effort is lower in the rivers and channels than the lagoons, but species richness is higher (Agostinho et al., 2000). Although floods seem to have a homogenization effect on the aquatic environments of the floodplain (Thomaz et al., 2007), the consequences for fish assemblages are poorly understood. This is primarily because of the importance of local process operating at the habitat scale during low water (Rodriguez \& Lewis, 1994). Information on Paraná River fishes, accumulated during the last decade, demonstrates distinct ecological responses to the annual pattern of flooding (Agostinho et al., 2000).

The principal characteristic distinguishing the extended floodplain of the Paraná River, downstream from its confluence with the Paraguay River, is the quantity of many small, shallow, and densely vegetated lakes (Carignan \& Neiff, 1992). These lakes are periodically connected to the river during high water, but the frequency, duration, and timing of the connections vary with river stage and with the topographic position of the lakes in relation to the main channel (Neiff, 1990). Thus, both spatial and temporal pattern associated with seasonal changes in the water level are important factor in this subtropical floodplain.

The importance of vegetated floodplain lakes as sites for development of young migratory fish, as well as refuge and feeding areas, has been indicated by several investigations (Bonetto, 1986; Agostinho et al., 2000; Canón Verón, 2005). However, fish communities associated with macrophytes are composed of small sized species, typical of lentic environments, and a few juveniles of large sized migratory species (Cordiviola de Yuan et al., 1984; Delariva et al., 1994; Meschiatti et al., 2000). Difficulties associated with sampling methods may be the reason for the scarcity of studies on fish assemblages in small, vegetated lagoons (Meschiatti et al., 2000). Despite the importance of the area covered by small water bodies at a globalscale, studies on these aquatic systems have been underemphasized (Downing et al., 2006).

In this paper, we compared the composition and abundance of fish assemblages in seven vegetated floodplain wetlands among different hydrological conditions: after a prolonged connection of the floodplain with the main channel, during receding water, and after a prolonged isolation. Beta diversity was measured for each hydrological condition as an integrator of habitat heterogeneity across a connectivity gradient within the floodplain. We also investigated the size and abundance of large sized migratory species found in the vegetated wetlands and the food resources exploited by the dominant fish.

We hypothesized that: 1- at each hydrological condition, the turnover in species richness exhibits a different pattern; 2- different species of small sized fishes, either species typical of lentic environment or young individuals of large sized migratory species, dominate the vegetated floodplain lakes at different hydrological conditions; and 3- there are assemblages of ubiquitous species that use a broad spectrum of feeding resources in high water and low water.

Results of this paper were expected to elucidate the importance of spatial and seasonal changes associated with the hydrologic regime of the Paraná River for fish assemblages in small vegetated wetlands. The importance of vegetated areas as substrate for development of fish juveniles and feeding habitat are also discussed.

\section{Material and Methods}

Site description. The studied area is located on the west bank of the Paraná River, $30 \mathrm{~km}$ downstream from the confluence with the Paraguay River (Fig. 1) and within the RAMSAR Site Wetlands CHACO (Argentine). As area and connection of the floodplain lagoons affect fish assemblages (Welcomme, 1985), we chose seven adjacent sites (Fig. 1) distributed in 1458 ha that reflected different local habitat conditions (lotic and lentic; temporary and permanent) with different connectivity to the main channel.

Site $1\left(27^{\circ} 25^{\prime} 42^{\prime \prime} \mathrm{S}, 58^{\circ} 52^{\prime} 10^{\prime \prime} \mathrm{W}\right)$ is a typical small stream that is $40 \mathrm{~m}$ wide, and its banks offer support for rooted aquatic plants dominated by Panicum elephantipes and Polygonum acuminatum. During high water, this channel transports water and material from the Paraná River to the floodplain at a mean velocity of $0.73 \mathrm{~m} \cdot \mathrm{s}^{-1}$. During low water, current velocity becomes markedly reduced and in some situations, flow ceases producing temporary lentic characteristics. Site $2\left(27^{\circ} 26^{\prime} 22^{\prime \prime} \mathrm{S}\right.$, $\left.58^{\circ} 51^{\prime} 13^{\prime \prime} \mathrm{W}\right)$ and Site 3 (27.26'09'S, 58 51'28'W) are oxbow lakes, periodically connected to the Paraná River. Both lagoons sustain high amounts of biomass of the floating macrophyte Eichhornia crassipes, which covers less than $50 \%$ of Site 2 and nearly $95 \%$ of the lake surface at Site 3 .

The other sites are small and very shallow (Table 1), remaining dry for more than six months in years with extremely low water levels. Different macrophytes: Scirpus giganteus (Site 4, 2725'53'S 58 51'52'W), Hymenachne amplexivaulis (Site 5, $27^{\circ} 25^{\prime} 51^{\prime \prime} \mathrm{S} 58^{\circ} 51^{\prime}$ '56”'W), Ludwigia peploides (Site 6, 27²5'46”S $58^{\circ} 51^{\prime} 58^{\prime \prime} \mathrm{W}$ ), as well as L. peploides and E. crassipes (Site 7, $27^{\circ} 25^{\prime} 42^{\prime \prime} \mathrm{S} 58^{\circ} 52^{\prime} 10^{\prime \prime} \mathrm{W}$ ) cover $40-50 \%$ of the area. During the prolonged isolation, sites 6 and 7 dried up completely.

The physical and chemical characteristics recorded in littoral areas of the study sites are shown in Table 1. Water temperatures were generally high and $\mathrm{pH}$ values were slightly acidic. Dissolved oxygen concentrations were usually lesser than $6.7 \mathrm{mg} . \mathrm{l}^{-1}$. Low concentrations $\left(0.5-0.9 \mathrm{mg} . \mathrm{l}^{-1}\right)$ were recorded in several sites during receding and isolation phases (Table 1).

Sampling. Fishes were sampled in the morning, during March 1999 (after a long lasting inundation phase of the Paraná River), September 1999 (at the beginning of a low water phase), and February 2000 (after a prolonged isolation) using a seine $(8.0 \mathrm{~m}$ $\mathrm{x} 1.50 \mathrm{~m}, 5 \mathrm{~mm}$ mesh). At each site and each sampling date, 4 seine hauls, covering an area of $10 \mathrm{~m}^{2}$ following the macro- 


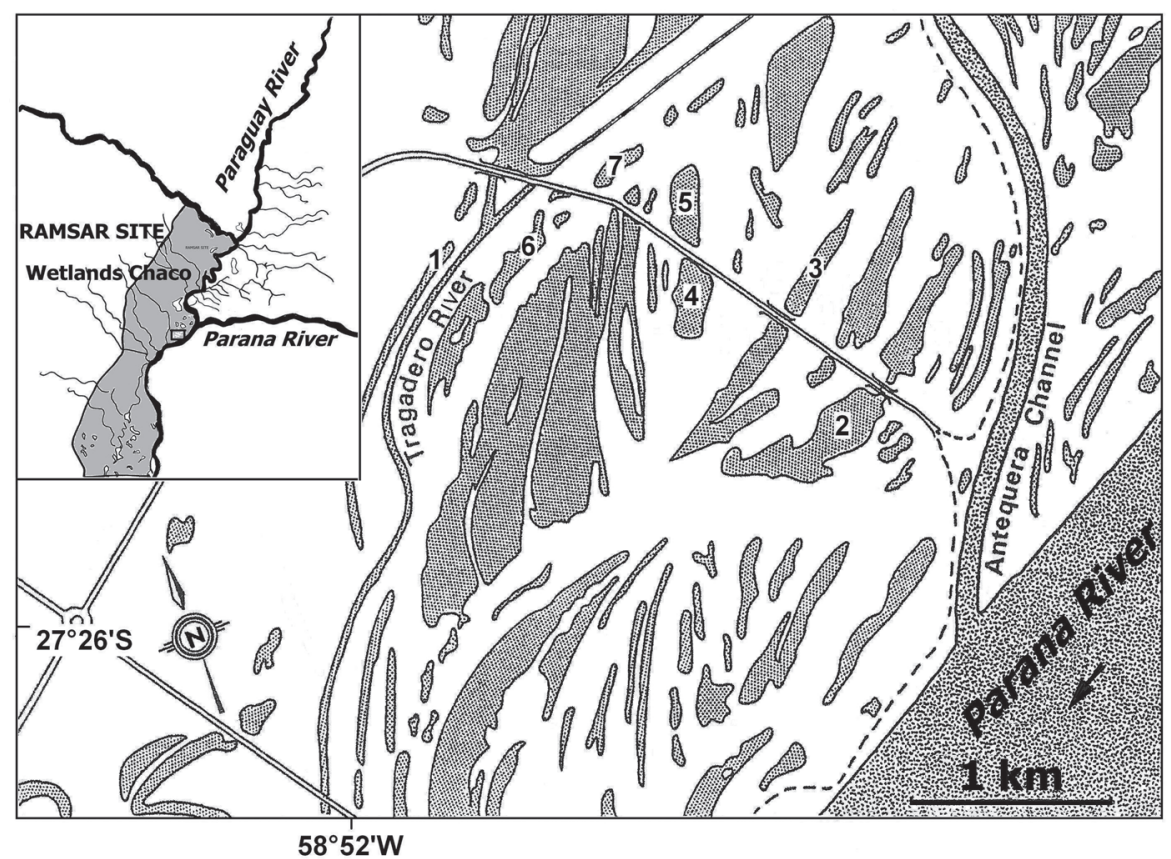

Fig. 1. Distribution of 7 vegetated wetlands across the studied alluvial floodplain. larity among fish assemblages from different sites, based on Jaccard distance (UPGMA method). The total species richness found in each hydrological condition was compared with the estimated species richness given by the second-order jackknife estimator, considering each site as unit $(\mathrm{n}=7)$. Beta diversity was estimated for each hydrological condition as an integrator of habitat heterogeneity across the floodplain using the Whittaker index with the modification introduced by Harrison (Magurran, 2004): $\beta \mathrm{w}=\{(\mathrm{S} / \alpha)-1\} /(\mathrm{N}-$ 1). 100 , where: $S=$ total number of species, $\alpha=$ mean species richness, and $\mathrm{N}=$ number of sites. The measure ranges from 0 (no turnover) to 100 (every sample has a unique set of species).

To examine spatial patterns in fish assemblages, the abundance of the $10 \mathrm{domi}-$ nant species were ordered using nonmetric multidimensional scaling (NMDS)

phytes banks, were conducted (sampled area $=40 \mathrm{~m}^{2}$ ). Fishes were counted, identified according to Ringuelet et al. (1967) and López et al. (2003), and standard length was measured. Voucher specimens were deposited in the Ichthyological Collection of Centro de Ecología Aplicada del Litoral (CECOALCONICET). The scientific names of species listed in Table II and III were reviewed according the Catalog of fishes, On-Line Version (http://www.calacademy.org/research/ichthyology/ catalog/fishcatsearch.html). In laboratory, gut content of the dominant fish was analyzed under a microscope; all plants and animals were identified to the lowest possible taxonomic level. We examined more than 20 stomachs with identifiable food items for each species, totaling 760 stomachs for the floodplain.

Data analysis. The connectivity of the wetlands was defined by determining the date for initial connection to the river in relation to the water level of the Paraná River in the gauge located near the study sites (Neiff \& Poi de Neiff, 2003). Due to disparities in the slopes of the study floodplain, topographic position of each site, rather than distances from the river, indicated the connectivity of each site. The number of flooding days (potamophase) for each site was calculated for the period from January 1997-January 2001 with the Software Pulse (Neiff \& Neiff 2003). The elasticity of the floodplain allows us to determine the variability in the habitat for fish, birds, and other organisms (Neiff et al., 1994). This index was calculated for the studied area, as the quotient between the maximum surface of water during the prolonged flooding and the minimum area occupied after the prolonged drought using LANDSAT 7 TM images representing May 1998 and January 2001, respectively.

Temporal variation in assemblage attributes (species richness and abundance) was analyzed with Kruskal Wallis test. The software EstiMates (Colwell, 1997) was used to calculate the Shannon-Wienner diversity index for each site and the simi- with a Bray-Curtis measure in PC-ORD (Version 4.17, 1999, MJM Software, Gleneden Beach, OR, U.S.A).

To express diet of the species, we used the frequency of occurrence of microcrustaceans, mollusks, terrestrial and aquatic insects, other invertebrates, fishes, algae, higher plants, and detritus. Results were ordered in a table and main trends were described.

\section{Results}

The hydrologic regime of the Paraná River was irregular with floods of different intensities, recurrences, and amplitudes (Fig. 2). Between January 1998 and January 1999, there was a

Table 1. Physical and chemical characteristics recorded in littoral areas of the study sites during different hydrological conditions.

\begin{tabular}{|c|c|c|c|c|c|c|c|}
\hline & \multicolumn{7}{|c|}{ Site 1 Site 2 Site 3 Site 4 Site 5 Site 6 Site 7} \\
\hline \multicolumn{8}{|c|}{ High Water } \\
\hline Temperature $\left({ }^{\circ} \mathrm{C}\right)$ & 20 & 23.3 & 22 & 24 & 24 & 24 & 24 \\
\hline Dissolved oxygen $\left(\mathrm{mg} . \mathrm{l}^{-1}\right)$ & 6.3 & 6.7 & 3.3 & 1.2 & 1.7 & 1.9 & 1.6 \\
\hline $\mathrm{pH}$ & 7.1 & 7.36 & 6.98 & 6.3 & 6.4 & 6.8 & 6.6 \\
\hline Conductivity $\left(\mu \mathrm{S} . \mathrm{cm}^{-1}\right)$ & 102 & 155 & 190 & 190 & 140 & 122 & 122 \\
\hline Depth $(\mathrm{m})$ & 6 & 1.80 & 1.50 & 0.85 & 1.25 & 0.80 & 0.93 \\
\hline Secchi $(\mathrm{cm})$ & 69 & 45 & 37 & 60 & 30 & 31 & 22 \\
\hline \multicolumn{8}{|c|}{ Receding Water } \\
\hline Temperature $\left({ }^{\circ} \mathrm{C}\right)$ & 18 & 18 & 18 & 23 & 23 & 18 & 23 \\
\hline Dissolved oxygen $\left(\mathrm{mg} \cdot \mathrm{l}^{-1}\right)$ & 3.3 & 3.7 & 2.4 & 0.9 & 1.2 & 0.9 & 2.2 \\
\hline $\mathrm{pH}$ & 7.9 & 6.7 & 6.6 & 6.3 & 6.2 & 6.7 & 6.1 \\
\hline Conductivity $\left(\mu \mathrm{S} . \mathrm{cm}^{-1}\right)$ & 150 & 230 & 260 & 390 & 340 & 305 & 150 \\
\hline Depth (m) & 4.30 & 1.6 & 1.07 & 0.6 & 0.9 & 0.40 & 0.34 \\
\hline Secchi $(\mathrm{cm})$ & 24 & 65 & 67 & 15 & 19 & 14 & 19 \\
\hline \multicolumn{8}{|c|}{ Isolation } \\
\hline Temperature $\left({ }^{\circ} \mathrm{C}\right)$ & 25 & 27 & 26 & 29 & 31 & & \\
\hline Dissolved oxygen $\left(\mathrm{mg} . \mathrm{l}^{-1}\right)$ & 2.2 & 2.5 & 0.5 & 0.6 & 0.75 & & \\
\hline $\mathrm{pH}$ & 7.32 & 6.8 & 6.6 & 6.3 & 6.5 & & \\
\hline Conductivity $\left(\mu \mathrm{S} . \mathrm{cm}^{-1}\right)$ & 205 & 245 & 340 & 418 & 360 & & \\
\hline Depth $(\mathrm{m})$ & 1.3 & 1.2 & 0.75 & 0.4 & 0.60 & & \\
\hline $\operatorname{Secchi}(\mathrm{cm})$ & 13 & 26 & 19 & 15 & 11 & & \\
\hline
\end{tabular}


long lasting hydrologic phase of the Paraná River, whereas between January 1999 and January 2000 there was a prolonged isolation phase. The sites were connected to the river above the hydrometric level, as indicated in Fig. 1. Scores from 1 to 7 indicate the decreasing order in connectivity according the number of days in which sites were connected to the river channel. The elasticity quotient for the studied area was 7.1.

Spatial and temporal pattern in assemblages attributes. A total of 100 species were captured in the 7 studied sites during low and high water phases, belonging to 8 orders, 26 families, and 70 genera (Table 2). Representatives from the order Characiformes, mainly comprised of small-sized species, dominated the samplings. Seventy species were recorded during the prolonged connection of the sites with the river, 58 during receding water and 33 during the isolation of the floodplain (Table 2). There were 33 species exclusive to the high water condition, whereas only 12 species were common amongst the three hydrological conditions (Table 2). The estimated species richness with the second order jackknife technique decreased from 106.8 and 98.8 (high and receding water, respectively) to 48.6 (isolation).

Despite the high total number of species registered, the number of species found in a particular site (sample species richness, Table 3) varied between 7 and 31 depending on the sampling site and the sampling date. During high water, sites that were more connected (1,2 and 3) presented higher values of density and species richness than sites less connected, but this pattern changed over receding water (Table 3 ). Thus, no significant differences in the abundance (Kruskal Wallis $=3.87$, $\mathrm{P}=0.1445$ ) or sample species richness (Kruskal Wallis $=3.92, \mathrm{P}$ $=0.1386$ ) were observed among different hydrological conditions. Species turnover decreased from high water $(\beta=40.33)$ to receding water $(\beta=33.83)$, with the minimum value of beta diversity index obtaining during the isolation of the floodplain $(\beta=26.83)$. Shannon-Wienner specific diversity varied site from site between 1.99 and 4.1 (Table 3).

Cluster analysis, based on presence-absence analysis, indicated low similarity (less than 35\%) among sites during both the isolation and the prolonged connection (Fig. $3 \mathrm{~A}, \mathrm{C}$ ). At high water, the three sites that were more connected were grouped and separated from others. During the receding water period, the similarity increases slightly and sites 1 and 3 were associated by $39.28 \%$ (Fig. 3B).

After the connection with the main channel, 8 species (Roeboides microlepis, Triportheus nematurus, Prionobrama paraguayensis, Moenkhausia dichroura, Moenkhausia sanctaefilomenae, Odontostilbe paraguayensis, Pimelodus maculatus and Gymnogeophagus balzanii) were relatively abundant and frequent (Table 2). Odontostilbe paraguayensis and Cyphocharax voga had high relative frequency (Table 2), while Prochilodus lineatus was the only species found in all sites (relative frequency $=100 \%$, Table 2). Other long distance migratory species (Pseudoplatystoma corruscans, Sorubim lima, Schizodon borellii and Raphiodon vulpinus) were found in low relative abundance during this hydrologic condition, whereas Pimelodus maculatus reached up to $4.29 \%$ of the captures.

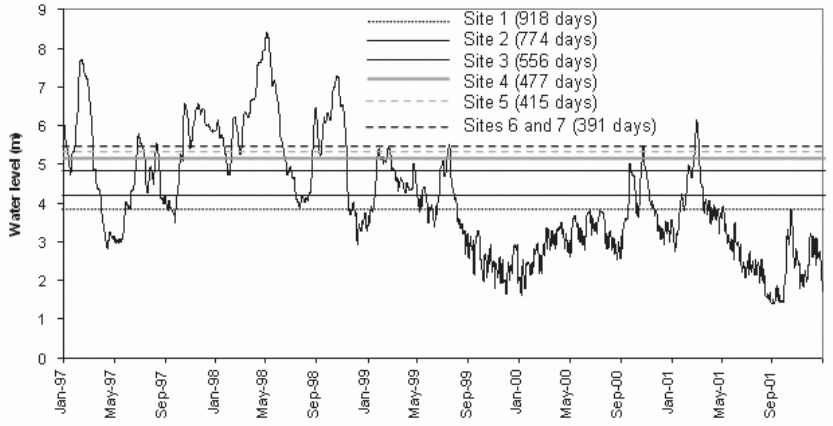

Fig. 2. Water level fluctuations of the Paraná River at Corrientes between 1997 and 2001. The Sites were connected with the Paraná River above the hydrological level indicated by the horizontal lines. The number of flooding days (in parentheses) indicates the connectivity between the floodplain and the river channel.

During receding water, the most frequent species (found in more than $85 \%$ of the sites, Table 2) were Cyphocharax voga, Odontostilbe pequira, Astyanax bimaculatus, Hyphessobrycon eques, and Hoplias malabaricus. The first of these, with $12.99 \%$ of the captures, was the most abundant. The migratory fish species registered during receding water were $P$. lineatus, Leporinus obtusidens, Leporinus acutidens, Leporinus octofasciatus, and Pimelodus albicans, which had low relative abundance $(<1 \%$, Table 2$)$.

After the prolonged isolation, 6 species (Astyanax bimaculatus, Serrapinnus calliurus, Diapoma terofali, Parodon suborbitalis, Gymnogeophagus balzanii, and Moenkhausia intermedia) accounted for $80 \%$ of the total abundance. Serrapinnus calliurus and $D$. terofali had a high frequency (71\%, Table 2). Juveniles of three migratory species (Leporinus acutidens, Schizodon borellii, and Raphiodon vulpinus) were registered in this condition, but with low abundance. The rarest species was the lungfish Lepidosiren paradoxa, which can live buried in holes during the unfavorable period when the lagoons dry out.

The ordination (NMDS) had a relatively high final stress $(16.30 \%)$ and low instability $(<0.00005)$. The two-dimensional solution explained 0.58 of the total variation in the data set, with $0.291(50.5 \%)$ of the variation loaded on Axis 1 and $0.285(49 \%)$ loaded on axis 2 (Fig. 4). The axes explained significantly more variance than would be expected by chance based on the Monte Carlo permutation test $(p=0.03)$. The ordination showed good separation of taxa and hydrological conditions (Fig. 4) in both axes, without clumping of points. Sites at high water showed separation from those at receding water and isolation and were grouped on the lower left quadrant. The ordination indicated that differences in the abundance of dominant species were more important across hydrological conditions than across sites with different connectivity (spatial pattern). Axis 1 was driven primarily by the abundance of Moenkhausia dichroura $(\mathrm{r}=-0.612)$, Gymnogeophagus balzanii $(\mathrm{r}=-0.443)$, Roeboides microlepis $(\mathrm{r}$ $=-0.455)$, Serrapinnus calliurus $(\mathrm{r}=-0.529)$ and Astyanax bimaculatus $(\mathrm{r}=-0.443)$. Axis 2 was driven primarily by the abundance of Odontostilbe pequira $(\mathrm{r}=0.617)$, Cyphocharax $\operatorname{vog} a,(\mathrm{r}=0.530)$ and Odontostilbe paraguayensis $(\mathrm{r}=-0.503)$. 
Table 2. Relative abundance of the total number of individuals represented by each species (RA), range of standard length $(\mathrm{SL}, \mathrm{cm})$ and relative frequency which each was collected (RF) in different hydrological conditions.

\begin{tabular}{|c|c|c|c|c|c|c|c|c|c|}
\hline & \multicolumn{3}{|c|}{ Isolation } & \multicolumn{3}{|c|}{ Receding water } & \multicolumn{3}{|c|}{ High water } \\
\hline & RA & SL & $\mathrm{RF}$ & RA & SL & $\mathrm{RF}$ & RA & SL & $\mathrm{RF}$ \\
\hline \multicolumn{10}{|l|}{ LEPIDOSIRENIFORMES } \\
\hline \multicolumn{10}{|l|}{ Lepidosirenidae } \\
\hline Lepidosiren paradoxa & $<1$ & 10 & 14.3 & & & & & & \\
\hline \multicolumn{10}{|l|}{ CHARACIFORMES } \\
\hline \multicolumn{10}{|l|}{ Paradontidae } \\
\hline Apareiodon affinis & & & & $<1$ & $5.5-6.3$ & 14.3 & $<1$ & $8.0-9.5$ & 28.6 \\
\hline Parodon suborbitalis & 8.66 & $2.3-2.5$ & 14.3 & & & & & & \\
\hline Parodon sp. & & & & & & & $<1$ & $2.0-2.9$ & 14.3 \\
\hline \multicolumn{10}{|l|}{ Curimatidae } \\
\hline Steindachnerina brevipinna & & & & $<1$ & 9.5 & 14.3 & $<1$ & $5.0-11.0$ & 28.6 \\
\hline Steindachnerina $\mathrm{sp}$. & $<1$ & $6.5-6.7$ & 14.3 & $<1$ & $5.5-10.0$ & 28.6 & $<1$ & $10.0-11.0$ & 28.6 \\
\hline Cyphocharax voga & $<1$ & $2.5-5.5$ & 28.6 & 12.99 & $2.8-3.5$ & 85.7 & $<1$ & $4.1-11.0$ & 71.4 \\
\hline Cyphocharax saladensis & & & & 0.46 & $2.8-3.5$ & 14.3 & & & \\
\hline Potamorhina squamoralevis & & & & & & & $<1$ & $2.9-5.0$ & 42.8 \\
\hline Psectrogaster curviventris & & & & $<1$ & 5.5 & 14.3 & & & \\
\hline \multicolumn{10}{|l|}{ Prochilodontidae } \\
\hline Prochilodus lineatus & & & & $<1$ & $9.0-25.0$ & 71.4 & 1.86 & $1.6-25.0$ & 100 \\
\hline Anostomidae & & & & & & & & & \\
\hline Leporinus acutidens & $<1$ & $8-17.2$ & 28.6 & $<1$ & $9-20.5$ & 14.3 & & & \\
\hline Leporinus octofasciatus & & & & $<1$ & 9 & 14.3 & & & \\
\hline Leporinus obtusidens & & & & $<1$ & $5.0-5.8$ & 14.3 & & & \\
\hline Schizodon borellii & $<1$ & $1.7-2.0$ & 14.3 & & & & $<1$ & $1.7-6.0$ & 42.8 \\
\hline Crenuchidae & & & & & & & & & \\
\hline Characidium rachovii & 2.78 & $3.7-4.5$ & 42.8 & 2.03 & $2.5-5.0$ & 28.6 & & & \\
\hline Gasteropelecidae & & & & & & & & & \\
\hline Thoracocharax stellatus & & & & & & & $<1$ & $2.7-13.0$ & 42.8 \\
\hline Characidae & & & & & & & & & \\
\hline Charax leticiae & & & & $<1$ & $2.5-8.9$ & 28.6 & 1.24 & $3.2-4.0$ & 14.3 \\
\hline Charax stenopterus & $<1$ & $5.8-7.0$ & 28.6 & $<1$ & $2.0-3.4$ & 57.1 & & & \\
\hline Roeboides microlepis & & & & & & & 22.12 & $5.5-17.0$ & 42.8 \\
\hline Roeboides descalvadensis & & & & $<1$ & $5.5-7.2$ & 14.3 & $<1$ & $5.5-16.2$ & 14.3 \\
\hline Roeboides affinis & & & & $<1$ & $4.0-6.2$ & 14.3 & & & \\
\hline Cynopotamus argenteus & $<1$ & $6.0-10.0$ & 14.3 & & & & & & \\
\hline Triportheus nematurus & $<1$ & $1.8-5.0$ & 14.3 & $<1$ & 6.6 & 14.3 & 6.52 & $1.6-10.0$ & 42.8 \\
\hline Prionobrama paraguayensis & 1.19 & $2.0-4.8$ & 28.6 & $<1$ & $3.0-4.2$ & 71.3 & 3.27 & $4.0-9.0$ & 42.8 \\
\hline Aphyocharax anisitsi & 2.78 & $3.0-3.5$ & 14.3 & 2.65 & $2.5-4.0$ & 42.8 & & & \\
\hline Aphyocharax rathbuni & & & & 1.08 & $2.5-5.5$ & 42.8 & $<1$ & $2.7-4.0$ & 28.6 \\
\hline Diapoma terofali & 10.89 & $3.5-5.0$ & 71.4 & 1.39 & $3.9-5.0$ & 42.8 & 2.93 & $2.5-5$ & 57.1 \\
\hline Pseudocorynopoma doriae & 2.37 & $2.0-4.2$ & 28.6 & & & & $<1$ & $1.5-3.5$ & 42.8 \\
\hline Poptella paraguayensis & & & & $<1$ & $8.7-10.5$ & 14.3 & $<1$ & $6.2-9.0$ & 28.6 \\
\hline Astyanax abramis & & & & & & & $<1$ & $2.8-9.2$ & 28.6 \\
\hline Astyanax bimaculatus & 22.89 & $2.6-11.0$ & 57.1 & 5.04 & $3.2-8.2$ & 85.7 & & & \\
\hline Astyanax fasciatus & & & & 4.05 & $2.5-5.5$ & 42.8 & 2.54 & $2.0-5.5$ & 57.1 \\
\hline Astyanax eigenmaniorum & & & & $<1$ & $4.5-6.4$ & 14.3 & & & \\
\hline Astyanax lineatus & & & & 3.34 & $3.5-7.0$ & 57.1 & 1.13 & $1.5-8.0$ & 57.1 \\
\hline Astyanax pellegrini & & & & $<1$ & 9 & 14.3 & & & \\
\hline Astyanax taeniatus & & & & & & & $<1$ & $2.5-3.0$ & 28.6 \\
\hline Ctenobrycon alleni & & & & $<1$ & $3.7-6.0$ & 28.6 & $<1$ & $2.0-4.0$ & 28.6 \\
\hline Hyphessobrycon eques & 1.35 & $3.5-5.0$ & 28.6 & 2.95 & $1.5-8.5$ & 87.7 & $<1$ & $2.4-2.7$ & 28.6 \\
\hline Hyphessobrycon luetkenii & & & & $<1$ & $3.9-4.2$ & 14.3 & & & \\
\hline Hyphessobrycon sp. & & & & & & & $<1$ & $2.1-2.5$ & 14.3 \\
\hline Moenkhausia dichroura & & & & $<1$ & $2.0-7.0$ & 28.6 & 3.64 & $3.1-5.0$ & 57.1 \\
\hline Moenkhausia intermedia & 8.74 & $3.0-4.0$ & 28.6 & $<1$ & $3.0-3.5$ & 28.6 & & & \\
\hline Moenkausia sanctaefilomenae & $<1$ & $4.2-5.0$ & 28.6 & $<1$ & $3.0-4.5$ & 42.6 & 8.47 & $1.7-2.5$ & 14.3 \\
\hline Psellogrammus kennedyi & $<1$ & $3.0-5.4$ & 14.3 & 6.06 & $2.5-5.3$ & 42.8 & $<1$ & $3.2-4.5$ & 14.3 \\
\hline Tetragonopterus argenteus & & & & $<1$ & 6 & 14.3 & $<1$ & $8.0-9.0$ & 28.6 \\
\hline Cheirodon interruptus & & & & 7.76 & $2.1-4.2$ & 28.6 & & & \\
\hline Serrapinnus calliurus & 14.78 & $2.6-3.1$ & 71.4 & 10.31 & $2.0-5.3$ & 71.4 & $<1$ & $2.0-3.0$ & 14.3 \\
\hline Odontostilbe sp. & 6.20 & $3.0-6.0$ & 28.6 & & & & & & \\
\hline Odontostilbe paraguayensis & & & & & & & 8.78 & $1.2-5.2$ & 71.4 \\
\hline Odontostilbe pequira & 1.42 & $2.5-4.0$ & 28.6 & 30.24 & $2.0-4.7$ & 85.7 & & & \\
\hline Pygocentrus nattereri & 1.19 & $3.0-3.5$ & 14.3 & & & & $<1$ & 3.2 & 14.3 \\
\hline Serrasalmus maculatus & & & & & & & $<1$ & $2.5-24$ & 28.6 \\
\hline Mylossoma duriventre & $<1$ & $10.0-18.1$ & 14.3 & & & & $<1$ & 19.3 & 14.3 \\
\hline Acestrorhynchidae & & & & & & & & & \\
\hline Acestrorhynchus pantaneiro & & & & & & & $<1$ & $14.7-19.0$ & 28.6 \\
\hline Cynodontidae & & & & & & & & & \\
\hline Raphiodon vulpinus & $<1$ & $8.0-19.3$ & 14.3 & & & & $<1$ & $5.8-24.5$ & 28.6 \\
\hline
\end{tabular}


Table 2. Cont.

\begin{tabular}{|c|c|c|c|c|c|c|c|c|c|}
\hline & \multicolumn{3}{|c|}{ Isolation } & \multicolumn{3}{|c|}{ Receding water } & \multicolumn{3}{|c|}{ High water } \\
\hline & RA & SL & $\mathrm{RF}$ & RA & SL & $\mathrm{RF}$ & RA & SL & $\mathrm{RF}$ \\
\hline \multicolumn{10}{|l|}{ Erythrinidae } \\
\hline Hoplerythrinus unitaeniatus & & & & & & & $<1$ & 17.5 & 14.3 \\
\hline Hoplias malabaricus & $<1$ & $3.2-11.5$ & 28.6 & $<1$ & $5.8-26.0$ & 85.7 & $<1$ & $4.0-28$ & 57.1 \\
\hline \multicolumn{10}{|l|}{ Lebiasinidae } \\
\hline Pyrrhulina australis & $<1$ & $3.0-3.5$ & 14.3 & $<1$ & $2.0-3.8$ & 42.8 & $<1$ & $3.3-4.0$ & 14.3 \\
\hline \multicolumn{10}{|l|}{ SILURIFORMES } \\
\hline \multicolumn{10}{|l|}{ Callichthyidae } \\
\hline Corydoras hastatus & $<1$ & $1.9-3.0$ & 14.3 & 2.00 & $1.7-3.0$ & 57.1 & & & \\
\hline Hoplosternum littorale & & & & $<1$ & $12.0-15.5$ & 14.3 & & & \\
\hline \multicolumn{10}{|l|}{ Loricariidae } \\
\hline Hypostomus commersoni & & & & $<1$ & 16.5 & 14.3 & $<1$ & 3 & 14.3 \\
\hline Otocinclus vittatus & & & & $<1$ & $2.1-3.0$ & 14.3 & $<1$ & 19 & 14.3 \\
\hline Loricariichthys anus & & & & & & & $<1$ & $3.0-7.3$ & 14.3 \\
\hline Loricariichthys platymetopon & & & & $<1$ & $4.0-8.6$ & 14.3 & $<1$ & $9.2-24.5$ & 14.3 \\
\hline Pseudohemiodon platycephalus & & & & $<1$ & 8.6 & 14.3 & & & \\
\hline Rhinelepis aspera & $<1$ & 3.5 & 42.8 & $<1$ & 3.7 & 14.3 & & & \\
\hline Ricola macrops & & & & & & & $<1$ & $22.0-24.5$ & 42.8 \\
\hline \multicolumn{10}{|l|}{ Auchenipteridae } \\
\hline Trachelyopterus striatulus & & & & & & & $<1$ & $3.2-15.0$ & 28.5 \\
\hline \multicolumn{10}{|l|}{ Pimelodidae } \\
\hline Hypophthalmus edentatus & & & & & & & $<1$ & $3.2-8.0$ & 28.6 \\
\hline Microglanis cottoides & & & & & & & $<1$ & $3.0-5.0$ & 14.3 \\
\hline Pimelodella cristata & & & & & & & 1.27 & $6.0-15.0$ & 28.6 \\
\hline Pimelodella gracilis & & & & $<1$ & 6.9 & 14.3 & & & \\
\hline Pimelodella howesi & & & & $<1$ & 10.2 & 14.3 & $<1$ & 13 & 14.3 \\
\hline Pimelodella laticeps & & & & & & & $<1$ & $13.2-17.0$ & 28.6 \\
\hline Pimelodus albicans & & & & $<1$ & $5.0-8.5$ & 14.3 & $<1$ & $9.0-11.0$ & 14.3 \\
\hline Pimelodus argenteus & & & & & & & $<1$ & $3.0-5.0$ & 14.3 \\
\hline Pimelodus maculatus & & & & & & & 4.29 & $2.7-7.0$ & 14.3 \\
\hline Pseudoplatystoma corruscans & & & & & & & $<1$ & 6.3 & 14.3 \\
\hline Sorubim lima & & & & & & & $<1$ & $4.5-12.0$ & 14.3 \\
\hline Aspredinidae & & & & & & & & & \\
\hline Bunocephalus doriae & & & & & & & $<1$ & $3.5-4.0$ & 14.3 \\
\hline GYMNOTIFORMES & & & & & & & & & \\
\hline Hypopomidae & & & & & & & & & \\
\hline Brachyhyроротиs brevirostris & & & & $<1$ & $8.5-9.5$ & 14.3 & 1.24 & $7.0-16.0$ & 42.8 \\
\hline Sternopygidae & & & & & & & & & \\
\hline Eigenmannia virescens & $<1$ & $5.5-6.0$ & 14.3 & $<1$ & $2.8-12.0$ & 14.3 & $<1$ & 17.7 & 14.3 \\
\hline CYPRINODONTIFORMES & & & & & & & & & \\
\hline Rivulidae & & & & & & & & & \\
\hline Rivulus punctatus & & & & & & & $<1$ & 2.2 & 14.3 \\
\hline Anablepidae & & & & & & & & & \\
\hline Jenynsia multidentata & & & & & & & $<1$ & 3.5 & \\
\hline Poeciliidae & & & & & & & & & \\
\hline Phalloceros sp. & & & & $<1$ & 2.5 & 14.3 & & & \\
\hline SYNBRANCHIFORMES & & & & & & & & & \\
\hline Synbranchidae & & & & & & & & & \\
\hline Synbranchus marmoratus & & & & $<1$ & $14.0-21.5$ & 14.3 & & & \\
\hline PERCIFORMES & & & & & & & & & \\
\hline Sciaenidae & & & & & & & & & \\
\hline Pachyurus bonariensis & & & & & & & $<1$ & $8.0-12.0$ & 14.3 \\
\hline Plagioscion ternetzi & & & & & & & $<1$ & $2.7-24.0$ & 57.1 \\
\hline Cichlidae & & & & & & & & & \\
\hline Apistogramma borellii & & & & $<1$ & $1.7-4.0$ & 57.1 & & & \\
\hline Apistogramma commbrae & 3.40 & $2.0-4.0$ & 42.8 & & & & & & \\
\hline Australoheros facetus & & & & & & & $<1$ & 3.0.5.0 & 14.3 \\
\hline Bujurquina vittata & & & & $<1$ & 5 & 14.3 & & & \\
\hline Cichlasoma dimerus & 3.17 & $5.3-6.0$ & 42.8 & $<1$ & $3.7-8.2$ & 42.8 & & & \\
\hline Crenicichla lepidota & & & & $<1$ & $8.2-15.0$ & 14.3 & $<1$ & $4.9-13.0$ & 14.3 \\
\hline Gymnogeophagus australis & & & & $<1$ & $4.6-5.6$ & 71.4 & $<1$ & $2.0-8$ & 28.6 \\
\hline Gymnogeophagus balzanii & 13.83 & $2.0-15$ & 14.3 & & & & 1.98 & $4.2-13$ & 57.1 \\
\hline Gymnogeophagus gymnogenys & & & & & & & $<1$ & 4 & 14.3 \\
\hline Laetacara dorsigera & & & & & & & $<1$ & $2.0-6.5$ & 28.6 \\
\hline PLEURONECTIFORMES & & & & & & & & & \\
\hline Achiridae & & & & & & & & & \\
\hline Catathyridium jenynsii & & & & & & & $<1$ & $2.5-4.0$ & 14.3 \\
\hline
\end{tabular}


Table 3. Variation in the fish assemblage attributes in the studied sites during different hydrologic conditions.

\begin{tabular}{|c|c|c|c|c|c|c|c|}
\hline & Site 1 & Site 2 & Site 3 & Site 4 & Site 5 & Site 6 & Site 7 \\
\hline \multicolumn{8}{|c|}{ March 1999} \\
\hline Specific diversity & 2.77 & 2.93 & 4.11 & 2.86 & 2.17 & 2.56 & 2.20 \\
\hline Species richness & 31 & 25 & 29 & 13 & 13 & 14 & 18 \\
\hline Captures per $40 \mathrm{~m}^{2}$ & 1728 & 288 & 242 & 132 & 329 & 322 & 504 \\
\hline \multicolumn{8}{|c|}{ September 1999} \\
\hline Specific diversity & 1.99 & 2.2 & 2.8 & 2.34 & 2.8 & 3.06 & 2.8 \\
\hline Species richness & 19 & 20 & 19 & 15 & 15 & 21 & 25 \\
\hline Captures per $40 \mathrm{~m}^{2}$ & 779 & 876 & 164 & 691 & 180 & 1342 & 1717 \\
\hline \multicolumn{8}{|c|}{ February 2000} \\
\hline Specific diversity & 3.19 & 2.92 & 2.30 & 2.24 & 2.12 & & \\
\hline Species richness & 17 & 16 & 15 & 8 & 7 & & \\
\hline Captures per $40 \mathrm{~m}^{2}$ & 173 & 415 & 502 & 73 & 161 & & \\
\hline
\end{tabular}

Variation in size. The maximum standard length of the fish captured in different sites and hydrological condition was 28 $\mathrm{cm}$ and the size of large migratory fish varied between 1.6 and $25.0 \mathrm{~cm}$. (Table 2). During the isolation of the bodies of water, fish with size less than $5 \mathrm{~cm}$ of four species (Serrapinnus calliurus, Diapoma terofali, Parodon suborbitalis, and Moenkhausia intermedia) accounted for $43 \%$ of the total abundance (Table 2). During high water, there were small sized species $(<5 \mathrm{~cm})$ typical of lentic environments, even though the size of dominant species reached up to $17 \mathrm{~cm}$ (Table 2).

Diet. Our results suggest that most of the fish utilized several food resources (Table 4). The exception was H. malabaricus, which diet included only fish of small size (from 1.8 to $2.5 \mathrm{~cm}$ ), but this species was found in low density in the vegetated areas. During analysis of the diet of other fish, we found terrestrial insects and vegetal debris in carnivorous fish. Molluscs were not found in the gut content of fish in the studied floodplain. Higher plants served as the intake for ten species and were the main resource for Astyanax fasciatus and Diapoma terofali. Other diets (Gymnogeophagus balzanii and Triportheus nematurus) included seeds of Polygonum and Ludwigia.

Based on the diet of 38 species, microcrustaceans appeared in the diet of 29 species (Table 4), but had a high frequency of occurrence only in the stomachs of $R$. descalvadensis, $B$. brevirostris, $P$. doriae, $T$. nematurus, $S$. borellii, and $M$. sanctaefilomenae. Their diets included cladocerans (mainly Moina, Latonopsis, Leydigia, Bosmina, Ceriodaphnia and Chidoridae) and conchostraceans (Cyclestheria hislopii). In the gut content of Roeboides microlepis we found fish scales.

Juveniles of Prochilodus lineatus included diatom algae and filamentous algae (Eunotia, Nitzschia, Oedogonium, Gomphonema, Euglena, and Phacus) in their diet. Other fish, which also ingested algae (Table 4), consumed Navicula, Pinnularia, Spirogyra, Trachelomonas, and Aulacoseira distans in addition to the mentioned genera.

Detritus were the main resource for 13 fishes in the studied floodplain (Table 4). Insects (mainly Chironomidae larvae) also constituted an important food resource consumed by 23 species, with a high frequency of occurrence in four species (Table 4). Other insects exploited by fish were mayflies (Caenis and Callibaetis), bugs (Corixidae and Belostomatidae), dragonflies, caddisflies, and beetles (adults and larvae of Helodidae,
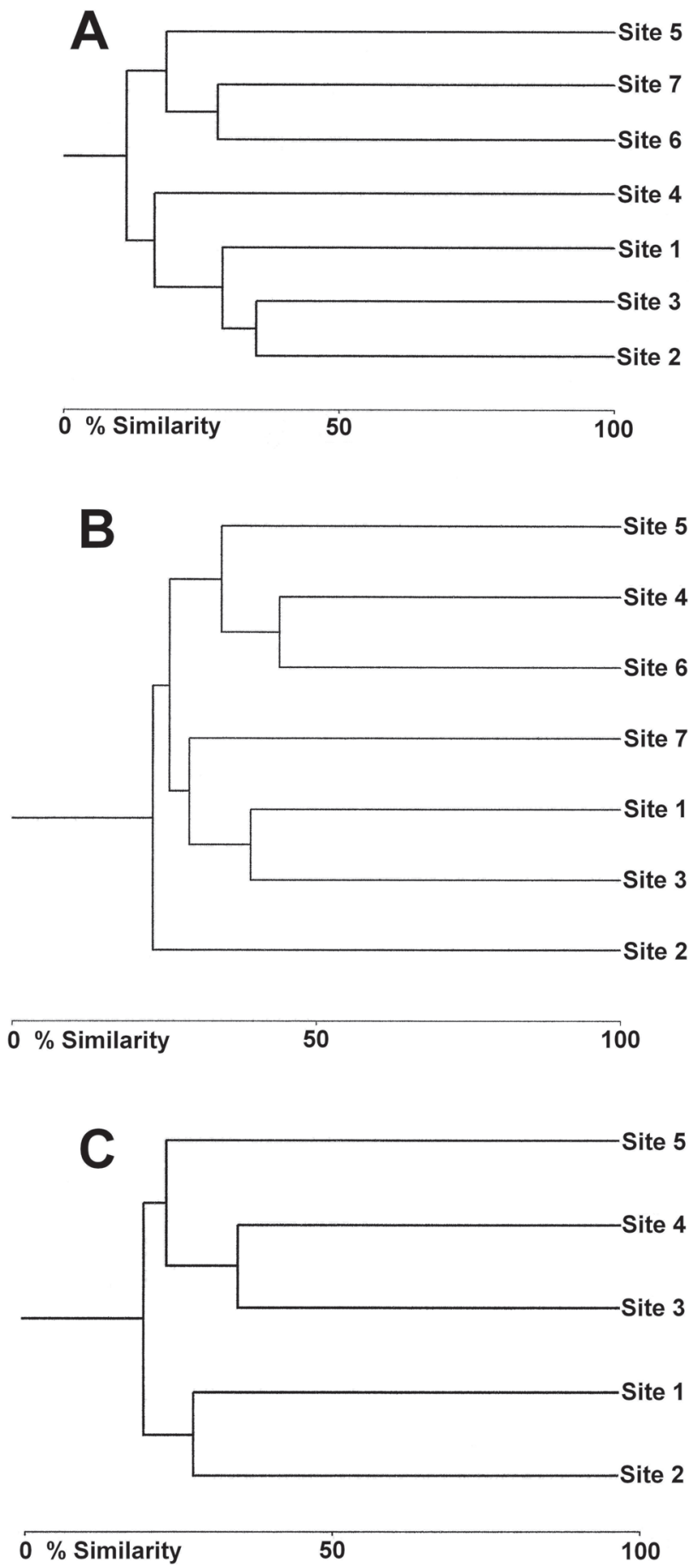

Fig. 3. Cluster analysis based on Jaccard distance (UPGMA method) of fish assemblages in the seven floodplain lakes. A. March 1999 (after a long lasting inundation phase of the Paraná River), B-September 1999 (at receding water) and CFebruary 2000 (during isolation).

Hydrophilidae, Dytiscidae and Curculionidae).

Dominant species during high water consumed microcrustaceans, diatoms, filamentous algae, and insects, whereas the dominant species in isolation conditions consumed aquatic plants, algae diatom and detritus. 


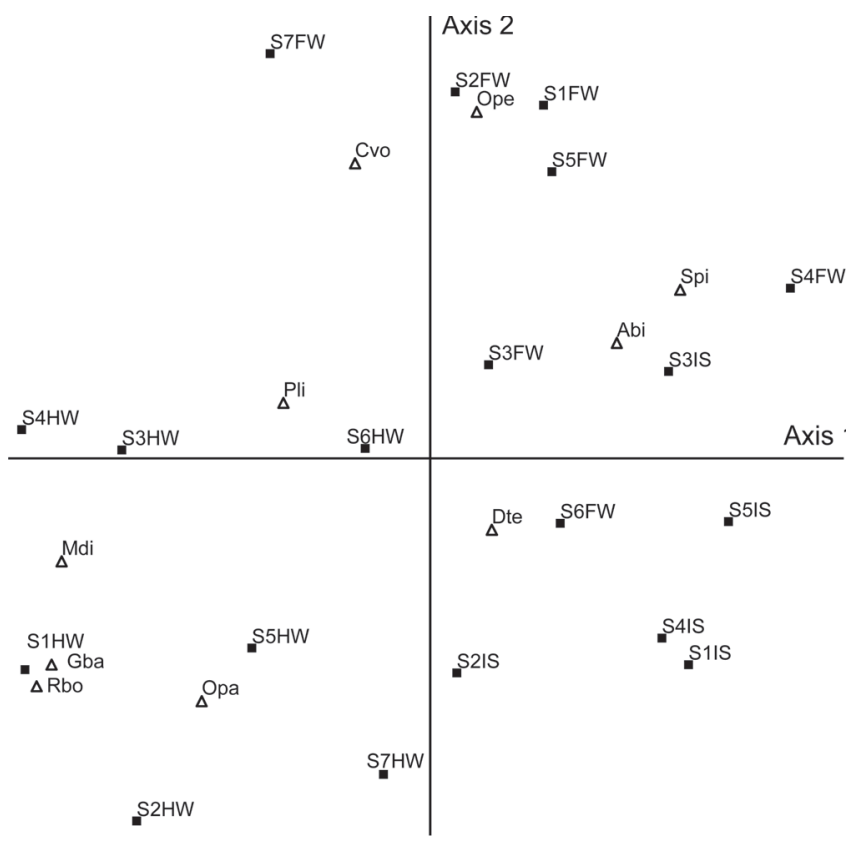

Fig. 4. NMDS ordination of dominant fish for different hydrologic condition (HW = high water, FW receding water, IS isolation) and sites (S). Ope $=$ Odontostilbe pequira, $\mathrm{Cvo}=$ Cyphocharax voga, $\mathrm{Spi}=$ Serrapinnus calliurus, $\mathrm{Abi}=$ Astyanax bimaculatus, $\mathrm{Pli}=$ Prochilodus lineatus, $\mathrm{Mdi}=$ Moenkhausia dichroura, $\mathrm{Gba}=$ Gymnogeophagus balzanii, $\mathrm{Rbo}=$ Roeboides microlepis, $\mathrm{Opa}=$ Odontostilbe paraguay ensis, Dte = Diapoma terofali.

\section{Discussion}

The number of species found in our studied area is high in comparison to the total species richness (216 species) reported for the middle Paraná River (Rossi et al., 2007). For 15 floodplain lakes located in this stretch, Cordiviola (1980) mentioned a total of 85 species during an isolation period, whereas Bonetto et al. (1969) found 75 species in 18 temporary lakes of a Paraná River tributary after they were connected to the river. The estimated number of species by the jackknife 2, during high water, was very similar to the total species richness for the three sampling dates (100 species). In contrast, data from the isolation period underestimated the total number of fish species. The high total species richness and the low number of sample species richness are consistent with the high spatial species turnover found in the studied floodplain. This pattern has been reported by Agostinho et al. (2004) for the upper Paraná River. In our study, the high beta diversity was maintained in both high and receding water, but decreased during isolation. Based on the data of Bonetto et al. (1969), other authors suggest that the relative abundance of fish vary stochastically from pool to pool in the middle Paraná River (Lowe-McConnell, 1987), which reflects local habitat conditions (Robinson et al., 2002) and the size of floodplain waterbodies (Welcomme, 1985). Our results indicated that different dominant populations occurred in different hydrological conditions, even though high water and isolation phases occur in the same season of different years.
The ordination (NMDS) indicates that species composition is not random and the importance of hydrological condition in structuring fish assemblages in the studied floodplain. The importance of rising and receding water has been recognized in stream ecology (Ward et al., 1999; Tockner et al., 2000), because wet areas can increase by several orders of magnitude during the annual floods. Highly variable assemblage composition within habitat types due to high spatial and temporal heterogeneity was found for large fish in a Venezuelan floodplain river (Layman \& Winemiller, 2005). The role of connectivity on fish assemblages and the effect of extended absence of flooding have been mentioned for the floodplain of other large rivers (Petry et al., 2003; Miranda, 2005; Pompeu \& Godinho, 2006)

As in other vegetated areas of the Paraná River floodplain, (Cordiviola de Yuan et al., 1984; Delariva et al., 1994; Meschiatti et al., 2000; Agostinho et al., 2003; Casatti et al., 2003), small sized characids, typical of lentic environments, dominated the fish assemblages, but with different fish composition. Although aquatic macrophytes has been indicated in the Paraná River as substrate for development of juveniles fish, refuge, feeding, and dispersion (Rossi et al., 2007), we found low relative abundance of the young stages of large sized migratory species in vegetated areas. Our findings are in agreement with other results obtained in vegetated areas of the upper Paraná River floodplain (Delariva et al., 1994; Meschiatti et al., 2000). The reproduction of migrating fish occurs in the main channel and in the secondary channels (Nascimento \& Nakatani, 2006), and is highly synchronized with the water level fluctuation of the Paraná River (Canon Verón, 2005). Spawning occurs at high water phase and, during the spring-summer peaks of ichthyoplankton, first development stages of Prochilodus lineatus and Leporinus obtusidens are abundant (Canon Verón, 2005). The lower stretch of the Paraná River is considered by Oldani \& Oliveros (1984) as the spawning and breeding area for P. lineatus, L. obtusidens, P. albicans, and S. lima. In spite of the limitation imposed by our scale, it appears that the proportion of juveniles of large migratory fish is low in all sites at different hydrological conditions. Therefore, further investigation is necessary in vegetated habitat with permanent connection to the river channel, to proper evaluate the role of these areas for development of young migratory fish.

Few species of Neotropical fish predominantly intake aquatic macrophytes as food, and many of these include other food resources in their diets (Agostinho et al., 2003). Our findings are in agreement with these results. In spite of being abundant in the macrophytes of the study floodplain (Poi de Neiff \& Carignan, 1997), snails are not prominent as a food resource for fish. The scarcity of molluses in the diet of fish has been indicated for the upper Paraná River (Hahn et al., 2004). As in other vegetated areas (Resende, 2000; Casatti et al., 2003), most fish used several feeding resources, but littoral macrophyte-associated organisms had a high frequency of occurrence. The abundance of generalist species in floodplain rivers is another indicator of the adjustment of populations to variations in the hydrologic regime (Junk, 2000). Most of the dominant species collected at low water can be classified into algivore/detritivore whereas at high water the abundance of invertebrate feeders 
Table 4 Frequency of occurrence (\%) of food resources exploited by the dominant fish in the Paraná River floodplain: 1-microcrustaceans; 2-molluscs; 3 -insects; 4-others invertebrates; 5-fishes; 6-algae; 7-higher plants; 8-detritus.

\begin{tabular}{|c|c|c|c|c|c|c|c|c|}
\hline \multirow[b]{2}{*}{ SPECIES } & \multicolumn{8}{|c|}{ SITES } \\
\hline & 1 & 2 & 3 & 4 & 5 & 6 & 7 & 8 \\
\hline Acestrorhynchus pantaneiro & 50 & - & - & 40 & 100 & - & - & 40 \\
\hline Aphyocharax anisitsi & 50 & - & - & 25 & - & 50 & 50 & - \\
\hline Astyanax fasciatus & 20 & - & - & - & - & 20 & 60 & 40 \\
\hline Astyanax lineatus & 20 & - & 30 & 10 & - & 60 & 50 & 20 \\
\hline Brachyhypopomus brevirostris & 100 & - & 60 & 20 & - & - & - & 60 \\
\hline Crenicichla lepidota & 50 & - & 50 & - & - & 25 & -1 & 100 \\
\hline Ctenobrycon alleni & 25 & - & 75 & 75 & - & 25 & - & - \\
\hline Cyphocharax voga & - & - & - & - & - & 75 & - & 90 \\
\hline Diapoma terofali & 50 & - & - & - & - & 50 & 80 & - \\
\hline Gymnogeophagus balzanii & 15 & - & 65 & - & 15 & 15 & 60 & 40 \\
\hline Hoplias malabaricus & - & - & - & - & 100 & - & - & - \\
\hline Loricariichthys anus & 40 & - & 50 & 40 & - & 40 & - & 70 \\
\hline Moenkhausia dichroura & 50 & - & - & - & - & 50 & - & 35 \\
\hline Moenkhausia sanctaefilomenae & 70 & - & - & - & - & 70 & - & 70 \\
\hline Odontostilbe paraguayensis & 40 & - & - & - & - & 80 & -1 & 100 \\
\hline Otocinclus vittatus & - & - & - & - & - & 100 & - & - \\
\hline Parodon suborbitalis & 30 & - & - & - & - & 100 & - & 100 \\
\hline Pimelodella laticeps & 50 & - & 40 & - & 40 & - & 20 & 60 \\
\hline Pimelodus maculatus & - & - & - & 40 & 50 & - & - & 100 \\
\hline Plagioscion ternetzi & - & - & - & 80 & 50 & - & - & 100 \\
\hline Poptella paraguayensis & 20 & - & 100 & - & - & - & 20 & - \\
\hline Potamorhina squamoralevis & 20 & & 30 & - & - & 100 & - & 20 \\
\hline Prionobrama paraguayensis & 35 & - & 10 & 10 & - & 20 & - & 80 \\
\hline Prochilodus lineatus & 20 & - & 5 & - & - & 100 & - & 100 \\
\hline Psellogramus kennedyi & 50 & - & 25 & 50 & - & 25 & - & 25 \\
\hline Pseudocorynopoma doriae & 100 & - & 20 & - & - & 80 & - & 20 \\
\hline Pseudoplatystoma corruscans & - & - & 20 & - & 100 & - & - & - \\
\hline Pygocentrus nattereri & - & - & 40 & - & 100 & - & - & - \\
\hline Raphiodon vulpinus & - & - & 20 & - & 100 & - & - & - \\
\hline Roeboides descalvadensis & 60 & - & 40 & 20 & 10 & - & 10 & 20 \\
\hline Roeboides microlepis & 40 & - & 60 & 10 & 30 & - & - & 25 \\
\hline Schizodon borellii & 100 & - & 60 & - & - & 60 & - & - \\
\hline Serrapinnus calliurus & 40 & - & - & - & - & 100 & - & - \\
\hline Serrasalmus maculatus & 30 & - & - & - & 100 & - & - & 50 \\
\hline Tetragonopterus argenteus & 45 & - & 25 & 10 & 20 & 10 & - & 90 \\
\hline Thoracocharax stellatus & 50 & - & 50 & - & - & 30 & - & 60 \\
\hline Trachelyopterus striatulus & - & - & 100 & - & - & 20 & 20 & - \\
\hline Triportheus nematurus & 100 & - & 50 & - & - & 50 & 50 & - \\
\hline
\end{tabular}

tended to increase. Retention of invertebrates by aquatic plants in the studied floodplain during high water (Poi de Neiff \& Carignan, 1997) could be affecting trophic relations by increasing the food resources for invertebrate feeders. Restrictions on the efficacy of piscivorous fish are expected to be higher in dense vegetated areas.

The studied floodplain has a high geomorphological heterogeneity, as evidenced by the high variation in physicochemical conditions, concentrations of nutrients, and decomposition rate of organic matter (Poi de Neiff et al., 2006), which is important for the fish diet. Also, the biomass of dominant aquatic plants (i.e. E. crassipes) is significantly different at different hydrological conditions (Neiff et al., 2008). The seasonal variation in fish assemblage composition described in this study, could be explained by changes in factors such as wetlands size (indicated by the elasticity quotient), hydrological connectivity, food resources availability and dissolved oxygen concentration in the water column, all recognized as important for fish distribution in floodplain lakes (Miranda, 2005). During receding and isolation of the floodplain dominant spe- cies at high water reduce its abundance and several species with adaptations to thrive in low oxygen conditions such as Lepidosiren, Corydoras, and Hoplosternum (Welcomme, 2000) were registered in some sites.

The high species richness of fish in the small, vegetated lakes is undoubtedly related to the high spatial and temporal heterogeneity. Disturbances in the hydrological regime of pulses could reduce the biodiversity by modifying the connectivity with the river channel and reducing the duration of the high water phase. Conservation of these vegetated wetlands requires maintenance of actual width range of connectivity that provide diverse habitat along time.

\section{Acknowledgements}

This study was financed by the PICT 12755 project ANPCYT (FONCYT) and PIP 6316 project (CONICET, Argentina). We are grateful to the technicians of CECOAL for their help during fieldwork, and two anonymous reviewers for helpful advices that improved the manuscript. We also thank Drs L. Malabarba and A. Agostinho for valuable suggestions to improve the presentation.

\section{Literature Cited}

Agostinho, A. A., L. M. Bini, L. C. Gomes, H. Ferreira Julio Jr., C. S. Pavanelli \& C. S. Agostinho. 2004. Fish assemblages. Pp. 223246. In: Thomaz, S. M., A. A. Agostinho \& N. S. Hahn (Eds.). The Upper Paraná River and its floodplain: physical aspects, ecology and conservation. Leiden, Backhuys Publishers. 393p.

Agostinho, A. A., L. C. Gomes \& H. Ferreira Julio Jr. 2003. Relação entre macrófitas aquáticas e fauna de peixes. Pp. 261-279. In: Thomaz, S. M. \& L. M. Bini (Eds.). Ecología e Manejo de Macrófitas Aquáticas. Maringá, EDUEM, 341p.

Agostinho, A. A., S. M. Thomaz, C. V. Minte-Vera \& K. O. Winemiller. 2000. Biodiversity in the high Paraná River floodplain. Pp. 89118. In: Gopal, B., W. J. Junk \& B. Davis (Eds.). Biodiversity in wetlands: assessment, function and conservation. Leiden, Backhuys Publishers. 353p.

Bonetto, A. A. 1986. Fish of the Paraná River system. Pp. 573-588. In: Davies, B. R. \& K. F. Walker (Eds.). The ecology of rivers systems. Dordrecht, Junk Publishers. 793p.

Bonetto, A. A., E. Cordiviola de Yuan, C. Pignalberi \& O. Oliveros. 1969. Ciclos hidrológicos del río Paraná y las poblaciones de peces contenidos en las cuencas temporarias de su valle de inundación. Physis, 29: 213-224.

Canón Verón, M. B. 2005. Patrones de distribución y abundancia de peces en el sistema de confuencia de los ríos Paraná y Paraguay. Unpublished Ph.D.Dissertation, Universidad Nacional de Córdoba, Córdoba, 175p.

Carignan, R. \& J. J. Neiff. 1992. Nutrient dynamics in the floodplain ponds of the Paraná River (Argentina) dominated by the water hyacinth Eichhornia crassipes. Biogeochemistry, 17: 85-121.

Casatti, L., H. F. Mendes \& K. M. Ferreira. 2003. Aquatic macrophytes as feeding site for small fishes in the Rosana reservoir, Paranapanema river, southeastern Brazil. Brazilian Journal of Biology, 63(2): 213-222.

Colwell, R. K. 1997. EstimateS: statistical estimation of species richness and shared species from samples (Software and User's Guide), Version 5. Available: http://viceroy.eed.unconn.edu/estimates. 
Cordiviola de Yuan, E. 1980. Campaña limnológica "Keratella I" en el río Paraná medio: taxocenos de peces de ambientes leníticos. Ecología, 4(1): 103-113.

Cordiviola de Yuan, E., E. Oldani, O. Oliveros \& C. Pignalberi de Hassan. 1984. Aspectos limnológicos de ambientes próximos a la ciudad de Santa Fe (Paraná Medio): poblaciones de peces ligados a la vegetación. Neotropica, 30(84): 127-139.

Delariva, R. L., A. A. Agostinho, K. Nakatani \& G. Baumgartner. 1994. Ichthyofauna associated to aquatic macrophytes in the upper Parana River floodplain. Revista Unimar (supl. 3): 41-60.

Downing, J. A., J. J. Cole, C. M. Duarte, L. J. Striegl, W. H. McDowell, K. Kortelainen, N. F. Caraco, J. M. Melack \& J. J. Middelburg. 2006. The global abundance and size distribution of lakes, ponds, and impoundments. Limnology and Oceanography, 51(5): 2388-2397.

Hahn, N. S., R. Fugi \& I de F. Andrian. 2004. Trophic ecology of the fish assemblages. Pp. 247-269. In: Thomaz, S. M., A. A. Agostinho \& N. S. Hahn (Eds.). The Upper Paraná River and its Floddplain. Leiden, Backhuys Publishers, 393p.

Junk, W. J. 2000. Mechanisms for development and maintenance of biodiversity in neotropical floodplains. Pp. 119-139. In: Gopal, B., W. J. Junk \& J. A. Davis (Eds.). Biodiversity in wetlands: assessment, function and conservation. Leiden, Backhuys Publishers, 353p.

Junk, W. J., P. B. Bailey \& R. E. Sparks. 1989. The flood pulse concept in river-floodplain systems. Pp. 110-127. In: Dodge, D. P. (Ed.). Proceedings of the International Large River Symposium. Otawa, Canadian (Special Publication) of Fishery and Aquatic Science 106, 629p.

Layman, C. A. \& K. Winemiller. 2005. Patterns of habitat segregation among large fishes in a Venezuelan floodplain river. Neotropical Icthyology, 3(1): 103-109.

López, H. A., M. Miquelarena \& R. C. Menni. 2003. Lista comentada de los peces continentales de la Argentina. ProBiota. Serie Técnica y Didactica N ${ }^{0}$. La Plata, 85p.

Lowe-McConnell, R. H. (Ed.). 1987. Ecological studies in tropical fish communities. Cambridge, Cambridge University Press, 382p.

Magurran, A. E. 2004. Measuring Biological Diversity. Oxford, Blackell Publishing, 256p.

Meschiatti, A. J., M. S. Arcifa \& N. Fenerich-Verani. 2000. Fish communities associated with macrophytes in Brazilian floodplain lakes. Environmental Biology of Fishes, 58: 133-143.

Miranda, L. E. 2005. Fish assemblages in oxboew lakes relative to connectivity with the Mississippi river. Transactions of the American Fisheries Society, 134:1480-1489.

Nascimento, F. L. \& K. Nakatani. 2006. Relações entre fatores ambientais e a distribuição de ovos e larvas de peixes na subbacia do rio Ivinhema, Estado de Mato Grosso do Sul, Brasil. Acta Scientiarum. Biological Sciences, 28( 2): 117-122.

Neiff, J. J. 1990. Ideas para la interpretación ecológica del Paraná. Interciencia, 15(6): 424-441.

Neiff, J. J. 2001. Diversity in some tropical wetland systems of South America. Pp.1-60. In: Gopal, B, W. Junk \& B. Davis (Eds.). Biodiversity in wetlands: assessment, function and conservation. Leiden, Backhuys Publishers, 311p.

Neiff, J. J., S. L. Casco \& A. Poi de Neiff. 2008. Response of Eichhornia crassipes (Pontederiaceae) to water level fluctuations in two lakes with different connectivity in the Paraná River floodplain. Revista de Biología Tropical 56(2): 613-623.

Neiff, J. J., M. H. Iriondo \& R. Carignan. 1994. Large Tropical South American Wetlands: An Overview. Proceedings of the International Workshop on the Ecology and Management of Aquatic-Terrestrial Ecotones: 156-165.
Neiff, J. J. \& M. Neiff. 2003. PULSO, software para análisis de fenómenos recurrentes. Dir. Nac. de Derecho de Autor N 236164 (Argentina) Buenos Aires, 17 de febrero. http:// www.neiff.com.ar.

Neiff, J. J. \& A. Poi de Neiff. 2003. Connectivity processes as a basis for the management of aquatic plants. Pp. 39-58. In: Thomaz, S. M. \& L. M. Bini (Eds.). Ecologia e Manejo de Macrófitas Aquáticas. Maringá, EDUEM, 341p.

Oldani, N. O. \& O. Oliveros. 1984. Estudios limnológicos en una sección transversal del tramo medio del río Paraná. XII: Dinámica temporal de peces de importancia económica. Revista de la Asociación de Ciencias Naturales del Litoral, 15(2): 175-183.

Petry, A. C., Agostinho, A. A. \& L. C. Gomes. 2003. Fish assemblages of tropical floodplain lagoons: exploring the role of connectivity in a dry year. Neotropical Ichthyology, 1(2): 111119.

Poi de Neiff, A. \& R. Carignan. 1997. Macroinvertebrates on Eichhornia crassipes roots in two lakes of the Paraná River floodplain. Hydrobiologia, 345: 185-196.

Poi de Neiff, A., J. J. Neiff \& S. L. Casco. 2006. Leaf litter decomposition in three wetland types of the Paraná River floodplain. Wetlands, 26: 558-566.

Pompeu, P. S. \& H. P. Godinho. 2006. Effects of extended absence of flooding on the fish assemblages of three floodplain lagoons in the middle São Francisco River, Brazil. Neotropical Ichthyology, 4(4): 427-433.

Resende, E. K. 2000. Trophic structure of fish assemblages in the lower Miranda river, Pantanal, Mato Grosso do Sul State, Brazil. Revista Brasileira de Biologia, 60(3): 389-403.

Ringuelet, R. A., R. H. Aramburu \& A. A. de Aramburu. 1967. Los peces argentinos de agua dulce. La Plata, Comisión de Investigaciones Científicas de la Provincia de Buenos Aires, 602p.

Robinson, C. T., K. Tockner \& J. V. Ward. 2002. The fauna of dynamic riverine landscapes. Freshwater Biology, 47: 661-677.

Rodriguez, M. A. \& W. M. Lewis Jr. 1994. Regulation and stability in fish assemblages of Neotropical floodplain lakes. Oecología, 99: 166-180.

Rossi, L. M., E. Cordiviola \& M. J. Parma. 2007. Fishes. Pp. 305325. In: Iriondo, M. H., J. C. Paggi \& M. J. Parma (Eds.). The Middle Paraná River: Limnology of a Subtropical Wetland. Berlin, Springer-Verlag, 382p.

Thomaz, S. M., L. M. Bini \& R. L. Bozelli. 2007. Floods increase similarity among aquatic habitats in river-floodplain systems. Hydrobiologia, 579: 1-13.

Tockner, K., C. Baumgartner, F. Schiemer \& J. V. Ward. 2000. Biodiversity of a Danubian floodplain: structural, functional and compositional aspects. Pp. 141-159. In: Gopal, B., W. Junk \& J. A. Davis (Eds.). Biodiversity in wetlands: assessment, function and conservation. Leiden, Backhuys Publishers, 353p.

Ward, J. V., K. Tockner \& F. Schiemer. 1999. Biodiversity of floodplain river ecosystems: ecotones and connectivity. Regulated Rivers: Research and Management, 15: 125-139.

Welcomme, R. L. 1985. River fisheries. Fisheries Technical Paper 262. Roma, FAO, 330p.

Welcomme, R. L. 2000. Fish biodiversity in floodplains and their associated rivers. Pp. 61-87. In: Gopal, B., W. Junk and J.A. Davis (Eds.). Biodiversity in wetlands: assessment, function and conservation. Leiden, Backhuys Publishers, 353p.

Accepted August 2008

Published March 31, 2009 